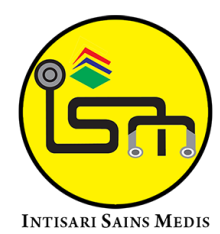

Published by Intisari Sains Medis

\section{Diagnosis dan penatalaksanaan tuberkulosis sistem saraf pusat}

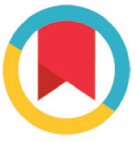

CrossMark

Prima Yogi ${ }^{*}$, I Putu Andrika ${ }^{2}$, I Gede Ketut Sajinadiyasa ${ }^{2}$, I Made Bagiada ${ }^{2}$

\section{ABSTRACT}

Introduction: Central nervous system (CNS) tuberculous are the most dangerous form of extrapulmonary TB. CNS tuberculous can present as meningoencephalitis, intracranial tuberculomas, and vasculitis. CNS tuberculous accounts for about $1 \%$ of all TB cases and is associated with high mortality. Tuberculous meningoencephalitis commonly presents with classic symptoms of fever, headache, meningism (neck stiffness), seizures as well as focal neurologic deficits, and altered consciousness. The diagnosis and treatment of CNS tuberculosis is still a formidable clinical challenge.

Case report: Patient presented with fever, headache, meningismus, convulsion, and decreased consciousness. CT scan showed cerebral tuberculoma in the left parietal lobe. Examination gene-Xpert of the cerebrospinal fluid showed Mycobacterium tuberculosis. The patient was given category 1 of antituberculosis drugs.

Conclusion: CNS tuberculosis has non-specific symptoms, difficult diagnosis, and high mortality. In this case report, the diagnosis of CNS tuberculosis was established based on the presence of Mycobacterium tuberculosis on the CSF molecular rapid test examination, and a CT scan of the head with contrast found cerebral tuberculoma.

Keywords: central nervous system, tuberculous.

Cite This Article: Yogi, P., Andrika, I.P., Sajinadiyasa, I.G.K., Bagiada, I.M. 2021. Diagnosis dan penatalaksanaan tuberkulosis sistem saraf pusat. Intisari Sains Medis 12(3): 912-916. D0I: 10.15562/ism.v12i3.1173

\title{
ABSTRAK
}

'Program Studi Pendidikan Dokter Spesialis Penyakit Dalam, Fakultas Kedokteran Universitas Udayana/ RSUP Sanglah, Denpasar, Bali Indonesia; ${ }^{2}$ Departemen/KSM Penyakit Dalam, Fakultas Kedokteran Universitas Udayana/RSUP Sanglah, Denpasar, Bali Indonesia;

\footnotetext{
*Korespondensi:

Prima Yogi;

Program Studi Pendidikan Dokter Spesialis Penyakit Dalam, Fakultas Kedokteran Universitas Udayana/ RSUP Sanglah, Denpasar, Bali Indonesia;

primayogi2@gmail.com
}

Diterima: 13-10-2021

Disetujui: 03-12-2021

Diterbitkan: 21-12-2021
Pendahuluan: Tuberkulosis sistem saraf pusat (SSP) adalah TB ekstrapulmoner yang paling berbahaya. Penyakit ini meliputi meningoensefalitis, tuberkuloma intrakranial, dan vaskulitis. Prevalensi tuberkulosis SSP sekitar 1\% dari semua kasus TB dan berhubungan dengan kematian yang tinggi. Meningoensefalitis tuberkulosis biasanya muncul dengan gejala demam, sakit kepala, meningismus, kejang, defisit neurologis fokal, dan penurunan kesadaran. Diagnosis dan pengobatan tuberkulosis SSP masih merupakan tantangan klinis yang berat.

Laporan kasus: Seorang pasien datang dengan

Kata kunci: sistem saraf pusat, tuberkulosis.

Sitasi Artikel ini: Yogi, P., Andrika, I.P., Sajinadiyasa, I.G.K., Bagiada, I.M. 2021. Diagnosis dan penatalaksanaan tuberkulosis sistem saraf pusat. Intisari Sains Medis 12(3): 912-916. D0I: 10.15562/ism.v12i3.1173

gejala demam, sakit kepala, meningismus, kejang, dan penurunan kesadaran. CT scan menunjukkan tuberkuloma serebral di lobus parietal kiri. Pemeriksaan tes cepat molekuler cairan serebrospinal menunjukkan Mycobacterium tuberculosis. Pasien diberikan obat anti tuberkulosis kategori 1.

Simpulan: Tuberkulosis SSP memiliki gejala yang tidak spesifik, diagnosis sulit, dan mortalitas tinggi. Pada kasus diagnosa tuberkulosis SSP ditegakkan berdasarkan adanya Mycobacterium tuberculosis pada pemeriksaan tes cepat molekular CSF, dan CT scan kepala dengan kontras dijumpai tuberkuloma serebral.

\section{PENDAHULUAN}

Tuberkulosis merupakan penyakit infeksi yang disebabkan oleh basil Mycobacterium tuberculosis. Tuberkulosis dapat mengenai berbagai organ. Tuberkulosis ekstra paru merupakan infeksi Mycobacterium tuberculosis pada organ lain selain parenkim paru. Tuberkulosis ekstra paru terjadi karena penyebaran basil
Mycobacterium tuberculosis melalui hematogen dan limfatik. Salah satu tuberkulosis ekstra paru yaitu tuberkulosis sistem saraf pusat. ${ }^{1}$

Tuberkulosis sistem saraf pusat 
(SSP) dapat mengenai parenkim, meningeal, intraventrikular, subdural, atau ekstradural. Prevalensi terjadinya tuberkulosis SSP sekitar 1,3\% dari semua kasus tuberkulosis dan 6,3\% dari kasus tuberkulosis ekstra paru.Tuberkulosis sistem saraf pusat (SSP) terutama muncul sebagai meningitis tuberkulosis, tuberkuloma, dan jarang sebagai abses otak tuberkulosis. Tuberkulosis SSP merupakan bentuk penyakit yang paling parah dan mengancam jiwa. ${ }^{2,3}$

Gejala klinis tuberkulosis SSP tidak spesifik. Gejala meningitis tuberkulosis meliputi demam, sakit kepala, muntah, kekakuan leher, kelelahan, kehilangan berat badan, kehilangan nafsu makan, perubahan sensorium, dan defisit fokal. Gejala tuberkuloma SSP bervariasi dengan lokasi lesi tetapi biasanya termasuk sakit kepala, kejang, defisit neurologis fokal, dan papilledema.,

Berikut ini kami laporkan sebuah kasus seorang laki-laki dengan tuberkulosis sistem saraf pusat (meningoensefalitis tuberkulosis, suspek tuberkuloma serebral, dan vaskulitis tuberkulosis). Laporan kasus ini menggambarkan pentingnya pemahaman tentang penegakan diagnosis dan penatatalaksanaan tuberkulosis SSP yang tepat.

\section{ILUSTRASI KASUS}

Seorang laki-laki, 32 tahun dikonsulkan dari bagian Neurologi. Pasien merupakan rujukan dari Rumah Sakit Umum Daerah. Pasien datang diantar keluarga ke UGD dengan keluhan penurunan kesadaran. Penurunan kesadaran terjadi sejak empat hari sebelum masuk rumah sakit (SMRS). Pasien dikatakan tidak dapat dibangunkan, dan mengorok sejak 4 hari SMRS. Pasien tampak kelemahan pada tubuh sebelah kanan. Pasien kejang 4 hari SMRS dengan pola kepala menoleh ke kiri kemudian sisi kiri menghentak. Saat kejang pasien tidak sadar. Setelah kejang pasien tidak sadar dan hanya merespon terhadap rangsangan nyeri saja.

Pasien dikatakan mengeluh nyeri kepala sejak 1 minggu sebelum masuk rumah sakit. Nyeri kepala dikatakan di seluruh bagian kepala. Nyeri kepala dirasakan sangat berat sehingga pasien tidak dapat beraktivitas. Nyeri kepala membaik setelah minum obat penghilang rasa sakit (parasetamol) namun nyeri kepala timbul lagi sekitar 3 jam setelah minum obat. Pasien mengeluh demam sejak 3 hari sebelum masuk rumah sakit. Demam dirasakan hilang timbul, dan membaik dengan penurun panas.

Pasien juga dikeluhkan batuk berdahak sejak 3 hari sebelum masuk rumah sakit. Pasien awalnya mengeluh batuk sejak 2 minggu namun setelah pasien tersedak, batuk dikatakan menjadi semakin sering. Batuk darah disangkal. Penurunan berat badan ada namun tidak diketahui berapa kilogram. Pasien dikatakan sesak sejak 1 hari sebelum masuk rumah sakit. Sesak dikatakan seperti pasien sulit bernafas.

Pasien didiagnosa suspek meningoensefalitis dan pneumonia di Rumah Sakit Daerah. Riwayat pengobatan yaitu Ceftriakson 2x2 gram intravena, levofloksasin 1x750 mg intravena, parasetamol 3x1 gram intravena. Pasien tidak ada riwayat tuberkulosis, kencing manis, penyakit ginjal, dan kanker. Riwayat keluarga menderita tuberkulosis disangkal. Pasien bekerja sebagai buruh bangunan. Pasien perokok 1 bungkus per hari

Pada pemeriksaan fisik didapatkan kesan umum sakit berat, kesadaran E2V2M5, tekanan darah 120/70 mmHg, nadi $108 \mathrm{kali} / \mathrm{menit}$, laju respirasi $30 \mathrm{x} /$ menit, $\mathrm{SaO}_{2} 85 \%$, suhu axilla $36,9^{\circ} \mathrm{C}$, indeks massa tubuh $15,62 \mathrm{~kg} / \mathrm{m}^{2}$. Pada pemeriksaan fisik ditemukan konjungtiva hiperemis, JVP $\mathrm{PR} \pm 0 \quad \mathrm{cmH}_{2} \mathrm{O}$, tidak ditemukan pembesaran kelenjar getah bening pada leher, aksila, dan inguinal. Pada pemeriksaan paru didapatkan inspeksi tampak simetris, pada palpasi ditemukan vokal fremitus sulit dievaluasi, pada perkusi ditemukan sonor, auskultasi ditemukan suara nafas vesikuler, ronkhi di basal paru kiri dan tidak ada wheezing. Pemeriksaan abdomen dan ekstremitas didapatkan dalam batas normal. Pada pemeriksaan fisik neurologis ditemukan kaku kuduk, paresis nervus VII Dextra supranuklear, kesan diparesis spastik, refleks Hoffmann tromner Dextra, Sinistra, refleks Babinski dan varian dextra sinistra.

Hasil laboratorium menunjukkan WBC $13,97 \times 10^{3} / \mu \mathrm{l}$, neutrophil $12,61 \times$ $10^{3} / \mu \mathrm{l}$, limfosit $0,65 \times 10^{3} / \mu \mathrm{l}$, monosit 0,64 x $10^{3} / \mu \mathrm{l}$, basofil $0,06 \times 10^{3} / \mu \mathrm{l}$, eosinofil 0 x $10^{3} / \mu \mathrm{l} \mathrm{RBC} 4,48 \times 10^{6} / \mu \mathrm{l}$, Hb $13,9 \mathrm{gr} / \mathrm{dl}$, HCT 39,53 \%, MCV 88,21 fL, MCH 31,02 $\mathrm{g} / \mathrm{dL}$, PLT $237 \times 10^{3} / \mu \mathrm{l}$, SGOT $33 \mathrm{U} / \mathrm{L}$, SGPT $20 \mathrm{U} / \mathrm{L}$, GDS $120 \mathrm{mg} / \mathrm{dl}$, BUN 8,5, SC 0,43, pH 7,42, pCO 44 pO 50 , Beecf $5,9, \mathrm{HCO}_{3}-31,2 \quad \mathrm{SO}_{2} 86 \%$ natrium 133 $\mathrm{mmol} / \mathrm{L}$, kalium 3,56 mmol/L, PPT 14,2 detik, INR 1,02, APTT 30 detik, Ca 9,2 $\mathrm{mg} / \mathrm{dl}, \mathrm{Mg} 2 \mathrm{mg} / \mathrm{dl}$.

Pemeriksaan foto thorax AP (Gambar 1) didapatkan soft tissue tak tampak kelainan, tulang-tulang tak tampak kelainan, sinus pleura kanan dan kiri tajam, diafragma kanan dan kiri normal, jantung besar dan betuk kesan normal, CTR 47\%, trakea: letak di tengah, pulmo: tampak konsolidasi pada zona bawah paru kiri, corakan bronkovaskuler normal. Dari pemeriksaan foto thorax didapatkan kesan pneumonia.

Pemeriksaan CT scan kepala dengan kontras (Gambar 2) didapatkan lesi hipodens multiple, intraaxial batas tegas dengan perifocal edema disekitarnya pada lobus parietalis kiri yang pada pemberian kontras tampak ring enhancement, sulci dan gyri normal, sistem ventrikel dan cisterna normal, tak tampak deviasi dan cisterna normal, tak tampak deviasi midline struktur, tak tampak kalsifikasi abnormal, pons dan cerebellum tak tampak kelainan. Orbita dan mastoid kanan kiri tak tampak kelainan, tampak penebalan mukosa sinus maxilaris kanan, ethmoidalis dan sphenoidalis kanan kiri, calvaria dan basis cranii tak tampak kelainan, SCALP tak tampak kelainan, kesan suspek cerebral tuberculoma pada lobus parietalis kiri, sinusitis maxilaris, ethmoidalis, dan sphenoidalis kanan kiri.

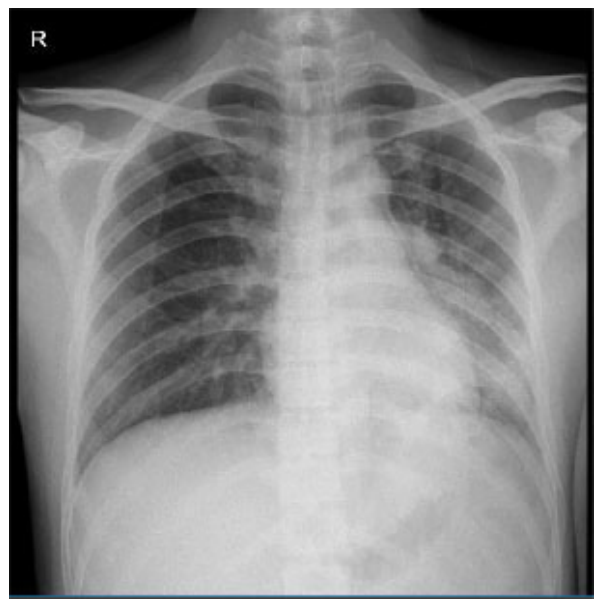

Gambar 1. Rontgen Thorax AP. 


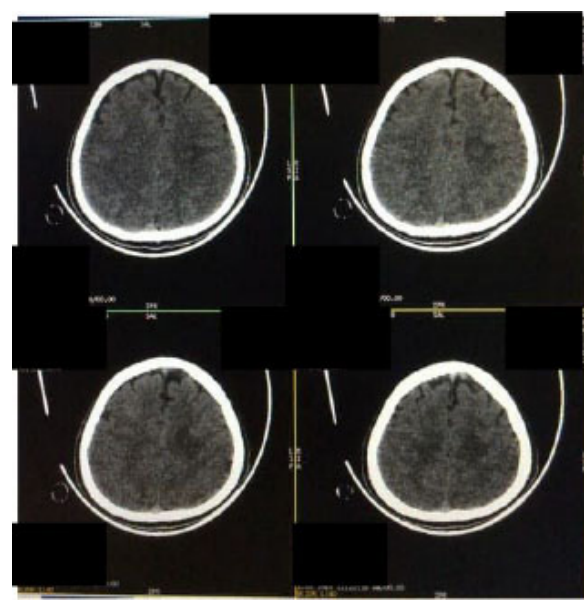

Gambar 2. CT scan kepala dengan kontras.

Pasien didiagnosis dengan meningoensefalitis tuberkulosis dd bakteri, suspek tuberkuloma serebral, pneumonia aspirasi, gagal nafas tipe 1, suspek tuberkulosis paru. Pasien dikonsulkan ke Bagian Intensif untuk dilakukan intubasi. Pasien diberikan terapi Infus $\mathrm{NaCl}$ 0,9\% 20 tetes/menit, diet cair $6 \times 200 \mathrm{ml}$, ceftriaxon $2 \times 2$ gram intravena, levofloksasin $1 \times 750$ $\mathrm{mg}$ intravena, deksametason $4 \times 5 \mathrm{mg}$ intravena, parasetamol 1 gram tiap 8 jam intravena, fenitoin $100 \mathrm{mg}$ tiap 8 jam intravena.

Hasil pemeriksaanlumbal pungsi empat hari kemudian didapatkan reaksi pandy $(+)$, reaksi none $(+)$, poly $5 \%$, eritrosit $25 /$ lapang pandang, bentuk normal, jumlah sel liquor $152 \mathrm{sel} / \mu \mathrm{l}$, makroskopis: warna jernih, darah negatif, bekuan negatif, mikroskopis: mono 95\%, glukosa 50, TP liquor/MTP: $111,2 \mathrm{mg} / \mathrm{dl}$. Tes cepat molecular LCS didapatkan hasil terdeteksi Mycobacterium tuberculosis medium dan tidak ada resistensi rifampisin. Tes cepat molecular bilasan lambung tidak terdeteksi Mycobacterium tuberculosis. Anti HIV didapatkan non reaktif. Pasien didiagnosa dengan tuberkulosis sistem saraf pusat (meningoensefalitis tuberkulosis, vaskulitis tuberkulosis, suspek tuberkuloma serebral), pneumonia aspirasi, gagal nafas tipe 1 . Pasien diberikan terapi OAT 4 FDC kategori 14 tablet tiap 24 jam dan streptomisin 1x1000 mg intramuskular.

Dalam waktu 13 hari perawatan kondisi pasien membaik dan dipindahkan ke ruang rawat inap dengan GCS E3V2M4, hasil kultur sputum: Pseudomonas aeruginosa.

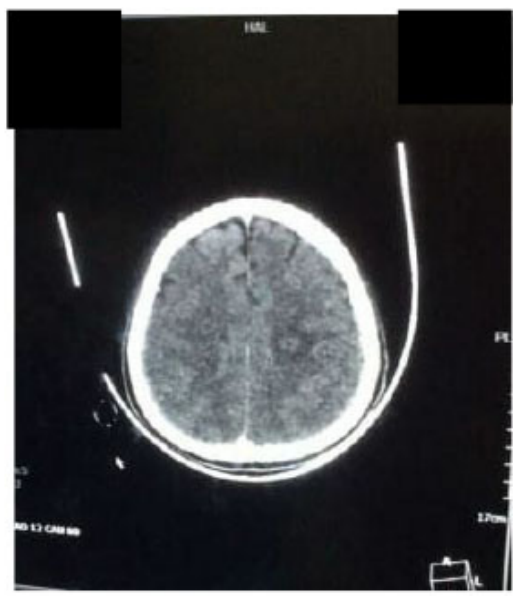

kelompok umur, tetapi paling sering terjadi pada anak-anak dan pada orang dengan infeksi HIV yang tidak diobati. Pada kasus, pasien berusia 32 tahun dan tidak terinfeksi HIV. ${ }^{6,7}$

Pada meningitis tuberkulosis terdapat eksudat basal yang terdiri dari limfosit, sel mononuklear, histiosit epiteloid dan area nekrosis dengan pembentukan granuloma. Meningitis tuberkulosis dapat menyebabkan komplikasi berupa tuberkuloma dan vaskulitis. Tuberkuloma intrakranial terjadi pada sekitar 4,5-28\% kasus dengan meningitis tuberkulosis. Faktor risiko tuberkulosis sistem saraf pusat (SSP) meliputi malnutrisi, malignansi, penggunaan obat-obatan imunosupresif, dan infeksi HIV. Pada kasus ini pasien mengalami meningoensefalitis tuberkulosis yang mengalami komplikasi berupa tuberkuloma dan vaskulitis. Faktor risiko terjadinya tuberkulosis SSP pada kasus yaitu malnutrisi. Tidak ada riwayat malignansi, penggunaan obat-obatan imunosupresif dan infeksi HIV pada kasus. ${ }^{3,4,8}$

Mycobacterium tuberculosis dapat menyebabkan infeksi tuberkulosis melalui airborne. Infeksi awalnya bereplikasi di paru-paru dan kemudian pindah ke kelenjar getah bening. Meningitis tuberkulosis terjadi karena penyebaran basil tuberkulosis melalui peredaran darah. Basil mengendap dan membentuk granuloma lokal yang disebut Rich focus di daerah meningen atau parameningeal. Pecahnya rich focus menyebabkan bacilli tumpah ke ruang subarachnoid, akhirnya melibatkan parenkim otak dan pembuluh darah. ${ }^{5,9}$

Keterlibatan parenkim otak dapat berupa tuberkuloma atau abses. Peradangan pada meningen menyebabkan eksudat basal di dasar otak dan menyebabkan vaskulitis yang dapat menyebabkan oklusi vaskular sehingga terjadi gejala seperti stroke. Pembuluh darah yang paling sering terlibat adalah perforasi cabang arteri serebri tengah yang mengarah ke infark di ganglia basal dan kapsul internal. Iskemia mungkin selanjutnya diperparah dengan meningkatnya tekanan intrakranial dan hidrosefalus akibat obstruksi cairan serebrospinal mengalir oleh basal eksudat. ${ }^{5,9}$ 
Gejala klinis meningitis tuberkulosis tidak spesifik. Gejala meningitis tuberkulosis meliputi demam, sakit kepala, muntah, kekakuan leher, kelelahan, kehilangan berat badan, kehilangan nafsu makan, perubahan sensorium, dan defisit fokal (kelumpuhan saraf kranial, kehilangan penglihatan, hemiparesis, dan paraparesis). Onset penyakit ini terjadi beberapa hari hingga minggu (kelelahan, penurunan berat badan / nafsu makan, dan keringat malam) diikuti oleh gejala meningitis (demam, sakit kepala, dan leher kaku). Jika tidak diobati, pasien dapat datang dengan berbagai komplikasi seperti sensorium yang berubah, kelumpuhan saraf kranial, hemiparesis, atau koma. Pada kasus, pasien mengalami demam, sakit kepala sejak 1 minggu sebelum masuk rumah sakit, kejang, penurunan berat badan dan keringat malam. Pada pemeriksaan fisik dijumpai kaku kuduk. ${ }^{5}$

Pemeriksaan analisis CSF sangat penting dalam membedakan meningitis dari diagnosis lain. Warna keruh menunjukkan konsentrasi leukosit yang signifikan dalam sampel (meskipun xanthochromia, konsentrasi protein tinggi atau jumlah pembentukan koloni bakteri tinggi). Protein CSF meningkat pada meningitis karena peningkatan permeabilitas sawar darah otak sebagai konsekuensi dari peradangan. Peningkatan ini biasanya lebih besar di meningitis tuberkulosis dan bakteri $(\geq 1$ $\mathrm{g} / \mathrm{L})$ dibandingkan pada meningitis virus $(<1 \mathrm{~g} / \mathrm{L})$. Pada mengitis tuberkulosis didapatkan analisa CSF yaitu, opening pressure normal/meningkat, leukosit CSF $100-500 \mathrm{sel} / \mathrm{ml}$, predominan limfosit, protein CSF $\geq 1 \mathrm{~g} / \mathrm{L}$, rasio glukosa darah/ CSF $\leq 0,5$. Pada kasus, pasien didiagnosa dengan meningoensefalitis tuberkulosis karena dari hasil lumbal pungsi didapatkan opening pressure normal, leukosit CSF 152, dominan limfosit, protein glukosa darah: $\mathrm{CSF} \leq 0,5 .{ }^{10}$

Diagnosis dan pengobatan meningitis tuberkulosis cepat merupakan indikator prognostik yang kuat untuk mengurangi kematian dan defisit neurologis. Deteksi basil tuberkulosis dapat dilakukan dengan beberapa pemeriksaan seperti Ziehl-Neelsen, kultur, dan tes cepat molecular. Pewarnaan Ziehl-Neelsen memiliki sensitivitas rendah dalam meningitis tuberkulosis hanya $10 \%-20 \%$. Kultur memiliki sensitivitas $60-70 \%$ tetapi membutuhkan waktu lama yaitu 10 hari di media cair dan 8 minggu di media padat. Tes cepat molekular adalah uji berbasis rantai polimerase untuk mendeteksi Mycobacterium tuberculosis dan mendeteksi mutasi terkait resistansi rifampisin. Tes cepat molekular memiliki sensitivitas $60 \%$ dan spesifisitas $100 \%$. Pada kasus, hasil pemeriksaan tes cepat molecular didapatkan Mycobacterium tuberculosis dan tidak ada resistensi rifampisin. ${ }^{5,9}$

Computed tomography (CT) dan magnetic resonance imaging (MRI) adalah modalitas yang umum digunakan untuk pencitraan. MRI memiliki resolusi yang lebih baik dalam mendeteksi tuberkuloma dan infark. Pada CT scan penderita meningitis TB didapatkan peningkatan meningeal basal, infark, tuberkuloma, abses tuberkulosis, dan hidrosefalus. ${ }^{6,11}$

Tuberkuloma adalah massa intra parenkim yang berbatas tegas dengan diameter mulai dari beberapa mm hingga 3-4 cm yang menyebabkan efek massa yang signifikan. Tuberkuloma dapat soliter atau ganda, keras, nodular, dan avaskular. Terdapat edema pada jaringan otak di sekitarnya. Secara mikroskopis, tuberkuloma merupakan massa jaringan granulasi yang terdiri dari tuberkel mikroskopis yang terdiri dari zona pusat nekrosis kasus yang dikelilingi oleh jaringan granulasi tuberkulosis yang terdiri dari banyak folikel yang terdiri dari sel-sel epiteloid, sel langerhans dan beberapa limfosit. Presentasi klinik dari tuberkuloma SSP bervariasi dengan lokasi lesi tetapi biasanya termasuk sakit kepala, kejang, defisit neurologis fokal, dan papilledema. Pada kasus, pasien mengalami sakit kepala, dan kejang., ${ }^{3,12}$

Tuberkuloma ditegakkan berdasarkan CT scan. Pada CT scan, tuberkuloma dikarakterisasi sebagai massa hypodense atau hyperdense dengan margin bulat atau berlobus. Lesi menunjukkan peningkatan homogen yang intens atau cincin dengan kontras. Dinding lesi tidak beraturan dengan bervariasi ketebalan. Edema perilesional sering terlihat. Tuberkuloma lebih sering terjadi pada lobus frontal dan parietal. Tempat yang lebih jarang tuberkuloma termasuk keterlibatan ganglia basal, batang otak, corpus callosum, dan ekstra aksial dan lokasi suprasellar. Setelah didiagnosis, respons radiografi tuberkuloma terhadap terapi dapat secara umum dinilai dalam 4 hingga 6 minggu. Hasil CT scan kepala dengan kontras pada kasus menunjukkan tuberkuloma serebral karena terdapat lesi hipodens multiple batas tegas dengan perifokal edema. Pada pemberian kontras tampak ring enhancement. Lokasi lesi di lobus parietalis kiri. ${ }^{2,8}$

Gejala vaskulitis tuberkulosis berupa gejala seperti stroke, dan dapat terjadi gangguan pergerakan seperti chorea, mioklonus. Sekitar 20\% pasien meningitis tuberkulosis mengalami stroke, sekitar $50 \%$ pasien ditemukan infark pada neuroimanging. MRI lebih sensitive dalam mendeteksi infark dibandingkan CT scan. Pada kasus, pasien mengalami gejala stroke yaitu hemiparesis kanan. Pada CT scan pasien tidak ditemukan infark. Hal ini dikarenakan CT scan kurang sensitif dalam mendeteksi infark dibandingkan MRI. ${ }^{13,14}$

WHOmerekomendasikan rejimenyang sama 2 bulan dari rifampisin, isoniazid, pirazinamid dan etambutol diikuti oleh 10 bulan rifampisin dan isoniazid untuk penatalaksanaan meningoensefalitis tuberkulosis. Berdasarkan guideline WHO tahun 2010, pada pengobatan meningitis tuberkulosis diberikan streptomisin untuk menggantikan etambutol. Namun berdasarkan guideline WHO tahun 2017, streptomisin sudah tidak direkomendasikan sebagai regimen standar untuk mengatasi tuberkulosis SSP. Hal ini dikarenakan streptomisin memiliki penetrasi CSF rendah dan menunjukkan efek samping toksisitas vestibular. Tidak dianjurkan melakukan operasi pada pasien tuberkuloma. Pada kasus pasien diberikan OAT kategori 1 dan streptomisin., ${ }^{5,15}$

$\begin{array}{ccr}\text { Terapi } & \text { kortikosteroid } & \text { dengan } \\ \text { pemberian } & \text { deksametason } & \text { atau }\end{array}$ prednisolone secara tapering 6-8 minggu dapat diberikan pada meningitis tuberkulosis. Kortikosteroid diberikan untuk mengurangi peradangan dan meningkatkan kelangsungan hidup pasien. Dosis deksametason intravena $0,4 \mathrm{mg} / \mathrm{kg} /$ 24 jam dalam 3-4 dosis terbagi. Pada kasus pasien diberikan deksametason $4 \times 5 \mathrm{mg}$. Perawatan suportif sangat diperlukan 
dalam tuberkulosis sistem saraf pusat. Terapi suportif termasuk penatalaksanaan kejang, dan ventilasi mekanis. Pada kasus pasien diberikan fenitoin, ventilasi mekanis, dan antibiotik untuk menangani pneumonia aspirasi.,16

Mortalitas dan komplikasi neurologis terjadi pada $50 \%$ pasien meningoensefalitis tuberkulosis meskipun sudah diberikan obat antituberkulosis. Usia tua $>60$ tahun, penurunan GCS saat awal masuk rumah sakit, defisit neurologis, hidrosefalus, dan waktu pemberian obat antituberkulosis yang terlambat merupakan faktor prognosis buruk pada pasien meningoensefalitis tuberkulosis. Pada kasus, pasien mengalami penurunan GCS dan defisit neurologis yang merupakan faktor prognosis buruk. ${ }^{17,18}$

\section{SIMPULAN}

Telah dilaporkan kasus seorang laki-laki, 32 tahun dengan tuberkulosis sistem saraf pusat (meningoensefalitis tuberkulosis, vaskulitis tuberkulosis dan suspek tuberkuloma serebral). Tuberkulosis SSP memiliki gejala yang tidak spesifik, diagnosis sulit, dan mortalitas tinggi. Pada kasus, pasien mengalami penurunan kesadaran, demam, kaku leher, kejang, nyeri kepala, penurunan berat badan. Diagnosa tuberkulosis SSP ditegakkan berdasarkan adanya Mycobacterium tuberculosis pada pemeriksaan tes cepat molekular CSF, dan CT scan kepala dengan kontras dijumpai tuberkuloma serebral.

\section{KONFLIK KEPENTINGAN}

Penulis melaporkan tidak ada konflik kepentingan.

\section{PENDANAAN}

Pada penulisan laporan kasus ini, tidak ada dana yang dikeluarkan maupun pemberian dana oleh pihak manapun.

\section{ETIKA DALAM PENELITIAN}

Pasien telah menandatangani secara tertulis lembar informed consent untuk foto klinis, data klinis dari pasien dapat dipublikasikan pada jurnal ilmiah kedokteran

\section{KONTRIBUSI PENULIS}

PY dan IPA bertanggung jawab terhadap evaluasi kasus, penulisan naskah publikasi, dan pemantauan harian kasus. IGKS dan IMB bertanggung jawab terhadap supervisi kasus dan membimbing dalam penyusunan naskah publikasi.

\section{DAFTAR PUSTAKA}

1. Zubair AS, Landreneau M, Witsch J, Fulbright RK, Huttner A, Sheth KN, et al. A critically ill patient with central nervous system tuberculosis and negative initial workup. Frontiers in Neurology. 2020;11:1-3.

2. Krishnan V, Mittal MK, Sinha M, Kumar M, Thukral BB. Central nervous system tuberculosis: rare presentations of a common disease. Astrocyte. 2017;4(3):174-185.

3. Kumar EA, Bai PJ. A clinical study of CNS tuberculomas. IAIM. 2016;3(6):101-106.

4. Zunt JR. Tuberculosis of the central nervous system. Continuum. 2018;24(5):1422-1438.

5. Vinny PW, Vishnu VY. Tuberculous meningitis. Journal of Current Research in Scientific Medicine. 2019;5:13-22.

6. Bouchaud O, Mechal F. Tuberculous meningitis: challenges in diagnosis and management. Revue Neurologique. 2019;175:451-457.

7. Seddon JA, Tugume L, Solomons R, Prasad $\mathrm{K}$, Bahr NC. The current global situation for tuberculous meningitis: epidemiology, diagnostics, treatment and outcomes. Welcome Open Research. 2019;4:1-15.
8. Shah IA, Asimi RP, Kawoos Y, Wani M, Sarmast AH. Tuberculomas of the brain with and without associated meningitis: a cohort of 28 cases treated with anti-tuberculosis drugs at a tertiary care centre. International Journal of Contemporary Medical Research. 2016;3(12):3484-3487.

9. Wilkinson RJ, Rohlwink U, Misra UK, Crevel RV, Mai NT, Dooley KE, et al. Tuberculous meningitis. Nat RFEv Neurol. 2017:13(10):581598.

10. Seddon JA, Tugume L, Solomons R. The current global situation for tuberculous meningitis: epidemiology, diagnostics, treatment and outcomes. Welcome Open Research. 2019;4(167):1-15.

11. Kee CP, Periyasamy P, Law ZK, Ibrahim NM, Yahya WNNW, Mhadzir H, dkk. Features and prognostic factors of tuberculous meningitis. Infect Dis Epidemiol. 2017;3:028.

12. Wang M, Luo L, Zhang Y, Liu X, Liu L, He J. Treatment outcomes of tuberculous meningitis in adults: a systematic review and meta-analysis. BMC Pulm Med. 2019;19(1):200.

13. Chatterjee D, Radotra BD, Vasishta RK, Sharma K. Vascular complication of tuberculous meningitis. Neurol India. 2015;63:926-932.

14. Wang Y, Li Q, Zhen X, Liu Y, Wu Q. Imunologic cerebral vasculitis and extrapulmonary tuberculosis: an uncommon association. Journal of Clinical and Diagnostic Research. 2015;9(9):3-5.

15. WHO. Treatment of tuberculosis guidelines. WHO. 2010:130-160.

16. WHO. Guidelines for Treatment of drug susceptible tuberculosis and patient care. WHO. 2017:1-80.

17. Anderson NE, Somaratne J, Mason DF. Holland D, Thomas MG. Neurological and Systemic complications of tuberculous meningitis and its treatment at Auckland City Hospital, New Zealand. J Clin Neurosci. 2010;17(9):11141118.

18. Gu J, Xiao H, Wu F, Ge Y, Ma J, Sun W. Prognostic factor of tuberculous meningitis. Int J Clin Exp Med. 2015;8(3):4487-4493.

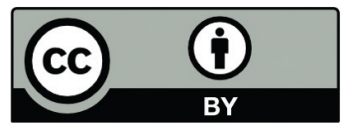

This work is licensed under a Creative Commons Attribution 